Article

\title{
Predominantly Ferruginous Conditions in South China during the Marinoan Glaciation: Insight from REE Geochemistry of the Syn-glacial Dolostone from the Nantuo Formation in Guizhou Province, China
}

\author{
Shangyi $\mathrm{Gu}^{1}{ }^{1} * \mathbb{D}$, Yong $\mathrm{Fu}^{1}$ and Jianxi Long ${ }^{2}$ \\ 1 College of Resource and Environmental Engineering, Guizhou University, Guiyang 550025, China; \\ byez1225@126.com \\ 2 Guizhou Geological Survey, Bureau of Geology and Mineral Exploration and Development of Guizhou \\ Province, Guiyang 550081, China; with-163@163.com \\ * Correspondence: sygu@gzu.edu.cn; Tel.: +86-0851-83627126
}

Received: 23 April 2019; Accepted: 3 June 2019; Published: 5 June 2019

\begin{abstract}
The Neoproterozoic Era witnessed two low-latitude glaciations, which exerted a fundamental influence on ocean-atmosphere redox conditions and biogeochemical cycling. Climate models and palaeobiological evidence support the belief that open waters provided oases for life that survived snowball Earth glaciations, yet independent geochemical evidence for marine redox conditions during the Marinoan glaciation remains scarce owing to the apparent lack of primary marine precipitates. In this study, we explore variability in rare earth elements (REEs) and trace metal concentrations in dolostone samples of the Cryogenian Nantuo Formation taken from a drill core in South China. Petrological evidence suggests that the dolostone in the Nantuo Formation was formed in near-shore waters. All the examined dolostone samples featured significant enrichment of manganese (345-10,890 ppm, average $3488 \mathrm{ppm}$ ) and middle rare earth elements (MREEs) (Bell Shape Index: 1.43-2.16, average 1.76) after being normalized to Post-Archean Australian Shale (PAAS). Most dolostone samples showed slight to no negative Ce anomalies ( $\mathrm{Ce}^{*} / \mathrm{Ce} 0.53-1.30$, average 0.95$)$, as well as positive $\mathrm{Eu}$ anomalies $\left(\mathrm{Eu}^{*} / \mathrm{Eu} 1.77-3.28\right.$, average 1.95). This finding suggests that the dolostone samples were deposited from suboxic to iron-enriched and anoxic waters. Although total REE concentrations correlated positively with Th concentrations in dolostone samples, MREE-enriched PAAS-normalized patterns preclude the conclusion that REEs were largely introduced by terrestrial contamination. Rather, we interpret the correlation between REEs and Th as an indication that the former were transported by colloids and nanoparticles in meltwaters. Taken together, we propose that anoxic and ferruginous water columns dominated in South China during the Marinoan glaciation with a thin oxic/suboxic layer restricted to coastal waters. The extreme anoxic and ferruginous conditions prevailing in the Cryogenian would have provided a baseline for subsequent transient Ediacaran ocean oxygenation and life evolution.
\end{abstract}

Keywords: Nantuo Formation; syn-glacial dolostone; rare earth elements; ferruginous conditions; South China

\section{Introduction}

The Neoproterozoic Era was characterized by two global Snowball Earth glaciations (the Sturtian and Marinoan glaciations), which extended to low latitudes [1]. The subsequent appearance of animal fossils and diversification of eukaryotes during the Ediacaran Period has been dubbed the Neoproterozoic Oxygenation Event [2-5]. It was initially proposed that ice covered the continents 
and oceans for several million years, which would have greatly reduced air sea-gas exchange [1]. As a result, atmospheric molecular oxygen would be exhausted by oxic weathering of the continents during the lengthy glaciations [6]. However, several lines of evidence have shown that this was not the case. Biomarkers and the benthic macro-algae fossil record have demonstrated that macroscopic phototrophs survived the Marinoan glaciation, with open water in coastal environments providing refuge for macro-algae [7-9]. Phototrophy, including that of eukaryotic algae, could also have persisted in meltwater and drainages on the sea glacier, producing a well oxygenated surface meltwater-based ecosystem in the equatorial zone of Snowball Earth [10-13]. Climate modeling allows for that an intermittent open water belt existed in low-latitude oceans during the Snowball Earth glaciation [14]. Redox-sensitive elements, iron speciation and nitrogen isotope data from diamictite support the existence of open marine waters and an oxygenated atmosphere during the Neoproterozoic Snowball Earth glaciations [6].

However, in contrast to the Sturtian glaciation, which was characterized by predominantly ferruginous conditions in marine chemistry, as indicated by the wide distribution of syn-glacial iron formation, few direct proxies have been seen to date for the redox condition of the Snowball Earth oceans [6]. A major problem in exploring seawater chemistry during the Marinoan glaciation has been the apparent lack of primary marine precipitates (such as carbonate), in which trace elements and stable isotopes (e.g., carbon and strontium) have been thought to provide a record of the seawater composition of ancient oceans $[15,16]$. Rare earth element (REE) compositions in carbonates are widely used to trace REE sources and oxygen levels in ancient ocean [17-22]. Here, we use rare earth and other trace elements found in bedded dolostone from the Nantuo Formation in South China to improve our knowledge of redox conditions during the Marinoan glaciation.

The dolostone samples analyzed in this study are derived from a drill core taken from the Nantuo Formation in the Yangtze Block of South China, specifically from a paleo-geographic slope environment in the Nanhua Basin (Figure 1). The sampled drill core is in Daotuo, about $14 \mathrm{~km}$ west of Songtao County, in eastern Guizhou Province. The Nantuo Formation ( 654-635 Ma) is correlated with the Marinoan global glaciation, according to radiometric dating [23-25]. Its thickness varies from several metres, along the shallow shelf, to more than $2000 \mathrm{~m}$, in the deep waters [25,26]. The Nantuo Formation is conformably underlain by the Datangpo Formation and is capped by dolostone 3-6 m thick at the base of the Doushantuo Formation [27].

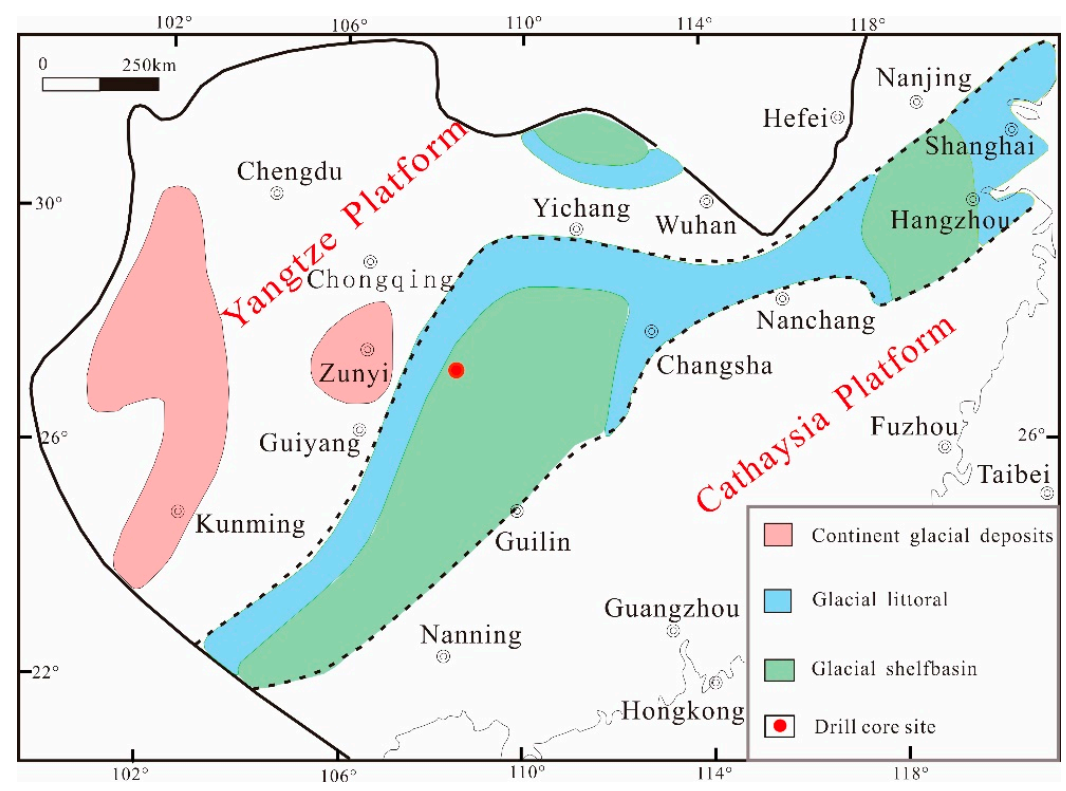

Figure 1. Paleogeographic map of the Nantuo Formation in South China (Modified after reference [27]). The red dot shows the locality of the drill core investigated in this study. 
The thickness of the Nantuo Formation in the drill core is about $245.5 \mathrm{~m}$, which is divided into four sections according to its lithofacies characteristics. The lower section is a coarsening-upward sequence composed of massive diamictites, representing the first episode of glaciation, when ice sheets reached the deep-water environment. The middle section is dominated by fine-grained siliciclastic lithofacies interbedded with a layer of laminated dolostone, which is a non-glacial marine deposit-an indication of glaciation's waning. The reappearance of massive diamictites and alternating coarseand fine-grained lithofacies in the upper Nantuo Formation forms the third section, indicating a dynamic ice-grounding line. The fourth section, at the top of the Nantuo Formation, is characterized by alternating massive sandstone-stratified sandstone and laminated siltstone, signifying the end of glaciation. Figure 2 provides detailed information on the studied drill core.

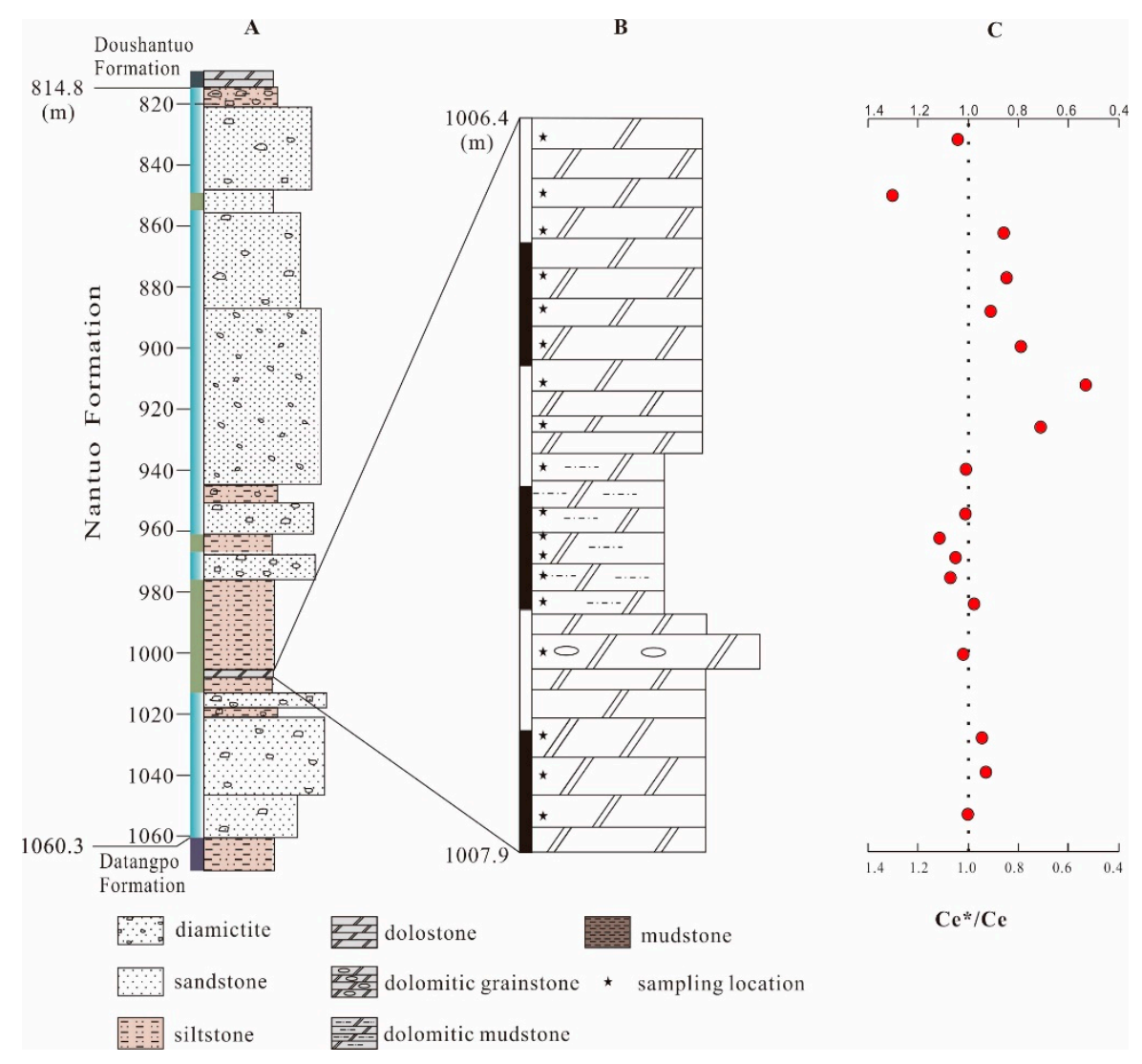

Figure 2. Stratigraphic $\log (\mathbf{A}, \mathbf{B})$ and the composite Ce anomaly chemostratigraphy $(\mathbf{C})$ of the Nantuo Formation from the Daotuo drill core in Guizhou Province, South China.

The dolostone bed intercalated in the mudstones is about $1.50 \mathrm{~m}$ thick and features micritic dolostones at its lower portion (ZK201-1-ZK201-4), calcareous mudstones at its middle (ZK201-5-ZK201-10), and micritic dolostones at its upper portion (ZK201-11-ZK201-18). Figure 3 depicts representative petrographic features, which can be seen under transmitted plane-polarized light. Massive grey dolomite with a micritic to microspar fabric was observed for all studied samples. Dolomitic peloids were found only in ZK201-4, where they varied in shape and size. These sedimentary structures indicate that the Nantuo Formation dolostones were deposited from a near-shore environment. 

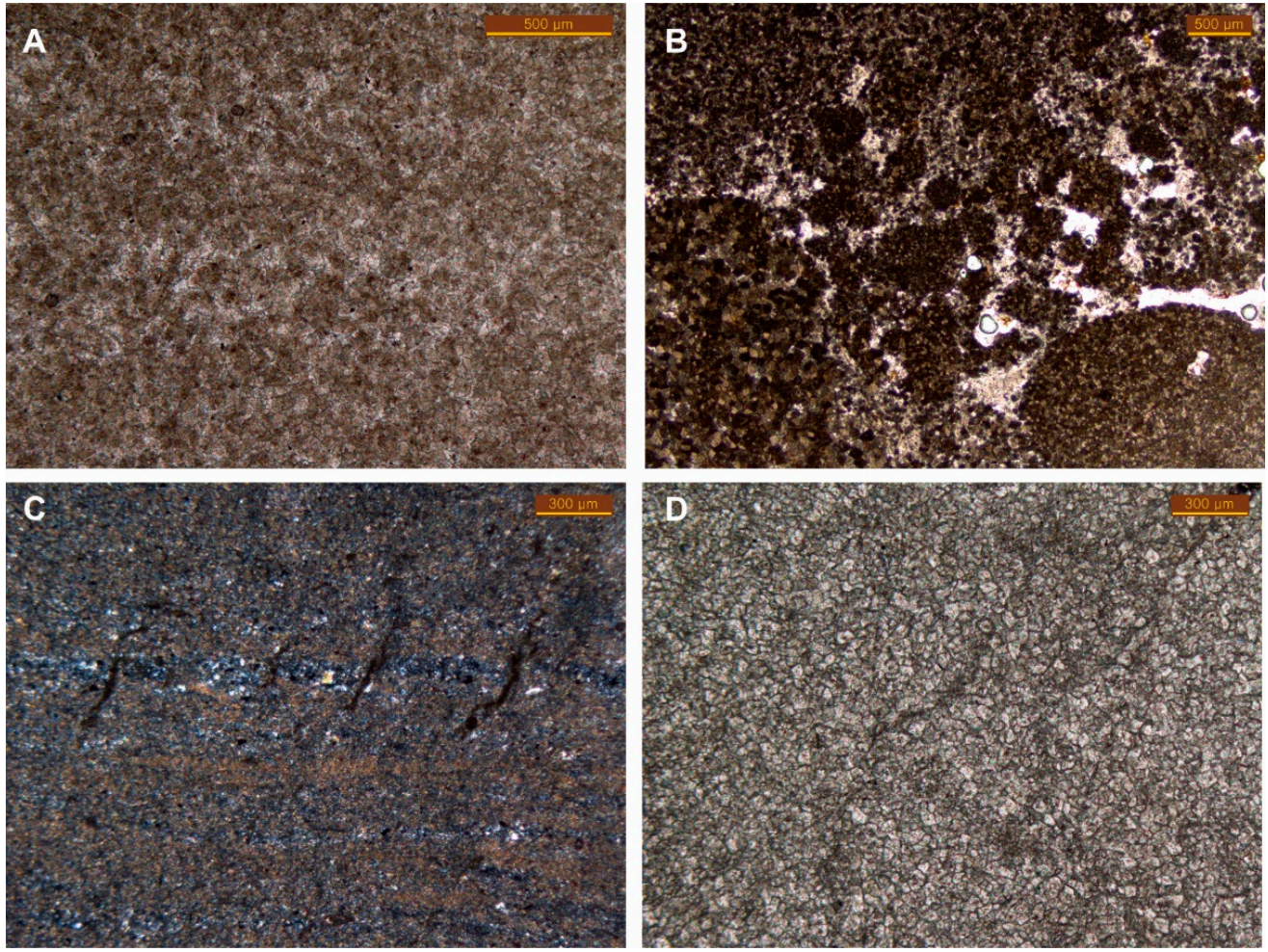

Figure 3. Transmitted plane-polarized light photomicrographs of petrographic thin sections showing micro-textures of Nantuo Formation dolostones from the Daotuo drill core in Guizhou Province, South China. (A) Micritic dolostone in sample ZK201-1. (B) Dolostone with peloidal fabrics in sample ZK201-4. (C) Calcareous mudstone in sample ZK201-8. (D) Micritic dolostone in sample ZK201-18.

\section{Materials and Methods}

Before sampling, a detailed petrographic analysis (including thin-section observation under polarizing microscope and staining with Alizarin Red S) was conducted on each sample. Scanning electron microscopy (SEM) using energy-dispersive (EDS) (SEM-EDS) analysis of selected samples confirmed that dolomite was the main chemical deposit in the samples. In all, 18 samples were obtained for chemical analysis by drilling with a $1 \mathrm{~mm}$ tungsten carbide micro-drill to ensure good spatial resolution. During sample drilling, visible veins and carbonate spars were avoided to ensure that samples represented their primitive deposits. About $500 \mathrm{mg}$ was drilled for each sample. Because the samples were not pure dolostones, and included variable contents of siliciclastics and sulphides, the traditional $\mathrm{HF}+\mathrm{HNO}_{3}+\mathrm{HClO}_{4}$ dissolution protocol would inevitably introduce varying amounts of non-carbonate components. In this study, we adopted the dissolution protocol used by [16]: About $100 \mathrm{mg}$ of a split of powder was caused to dissolve in $0.5 \mathrm{~mol} / \mathrm{L}$ sub-boiling distilled acetic acid at room temperature for $4 \mathrm{~h}$, and the resulting supernatant solution, after being centrifuged, was dried. Afterward, the dried solution was evaporated to dryness, refluxed with $\mathrm{HNO}_{3}$, dissolved in $2 \% \mathrm{HNO}_{3}$ to $50 \mathrm{~mL}$ and then analyzed by Thermo Fisher inductively coupled plasma mass spectroscopy (ICP-MS) at the National Research Center for Geoanalysis at the Chinese Academy of Geological Sciences, Beijing, China. Reference materials GSR-1, GSR-2, and GSR-3, which were used to monitor the analytical reproducibility, obtained results matching those expected for the REE and other trace element contents with analytical errors less than $5 \%$.

The predicted normalized concentrations of $\mathrm{La}^{*}, \mathrm{Ce}^{*}, \mathrm{Eu}^{*}$, as well as $\mathrm{La}, \mathrm{Ce}$ and $\mathrm{Eu}$ anomalies, were calculated by Post-Archean Australian Shale [28] (PAAS) normalization according to [29,30], using the following equations:

$$
\mathrm{La}^{*}=\operatorname{Pr}_{N}{ }^{*}\left(\operatorname{Pr}_{N} / \mathrm{Nd}_{N}\right)^{2}
$$




$$
\begin{gathered}
\mathrm{Ce}^{*}=\operatorname{Pr}_{N}{ }^{*} /\left(\operatorname{Pr}_{N} / \mathrm{Nd}_{N}\right) \\
\mathrm{Eu}^{*}=\mathrm{Sm}_{N}{ }^{*}\left(\operatorname{Sm}_{N} / \mathrm{Tb}_{N}\right)^{1 / 2} \\
\mathrm{La} / \mathrm{La}^{*}=\mathrm{La}_{N} /\left(\operatorname{Pr}_{N}{ }^{3} / \mathrm{Nd}_{N}{ }^{2}\right) \\
\mathrm{Ce} / \mathrm{Ce}^{*}=\mathrm{Ce}_{N} /\left(\operatorname{Pr}_{N}{ }^{2} / \mathrm{Nd}_{N}\right) \\
\mathrm{Eu} / \mathrm{Eu}^{*}=\mathrm{Eu}_{N} /\left(\mathrm{Sm}_{N}{ }^{2} \mathrm{~Tb}_{N}\right)^{1 / 3}
\end{gathered}
$$

where $\mathrm{REE}_{N}$ represents the REE value after PAAS normalization. We used Equation (5) to calculate the Ce anomalies in this paper. Additionally, $(\mathrm{Nd} / \mathrm{Yb})_{N}$ and $(\mathrm{Pr} / \mathrm{Yb})_{N}$ were calculated as indicating relative light/heavy REE ratios (LREE/HREE). $(\mathrm{Pr} / \mathrm{Tb})_{N}$ and $(\mathrm{Tb} / \mathrm{Yb})_{N}$ are calculated as parameters indicative of light/middle REE (LREE/MREE) and middle/heavy REE (MREE/HREE), respectively. The bell-shaped index (BSI) is calculated using the following equation to represent the enrichment of the MREE [30]:

$$
\mathrm{BSI}=\frac{2\left(S m_{N}+G d_{N}+D y_{N}\right) / 3}{\left(L a_{N}+P r_{N}+N d_{N}\right) / 3+\left(H o_{N}+E r_{N}+T m_{N}+Y b_{N}+L u_{N}\right) / 5} .
$$

It should be noted that anomalies are calculated on a linear scale in the majority of the literature, with $\mathrm{Ce} / \mathrm{Ce}^{*}$ and $\mathrm{Pr} / \mathrm{Pr}^{*}$, for example, expressed as follows [21,31]:

$$
\begin{aligned}
& \mathrm{Ce} / \mathrm{Ce}^{*}=2 \mathrm{Ce}_{N} /\left(\operatorname{Pr}_{N}+\mathrm{La}_{N}\right) \\
& \operatorname{Pr} / \operatorname{Pr}^{*}=2 \operatorname{Pr}_{N} /\left(\mathrm{Ce}_{N}+\mathrm{Nd}_{N}\right) .
\end{aligned}
$$

We inspected our data using both Equations (5) and (8) and found no critical differences.

\section{Results}

Tables 1 and 2 present the concentrations of the measured REEs and trace elements Th and Mn and calculated REE parameters, respectively. Figures $2 \mathrm{C}$ and 4 depict $\mathrm{Ce}$ anomaly variations and normalized patterns of REE distribution relative to the PAAS, respectively. All measured samples have consistently low REE concentrations of 3.30-29.77 ppm, high Mn concentrations of 345-10,890 ppm, and variable Th concentrations of 0.098-2.032 ppm. Despite differences in REE concentrations, these samples share similar REE patterns: (1) enrichment of MREE over both LREE ([Pr/Tb $]_{N}$ from 0.26 to 0.81 ) and $\mathrm{HREE}\left([\mathrm{Tb} / \mathrm{Yb}]_{N}\right.$ from 1.30 to 2.99 ) with BSI from 1.43 to 2.16 ; (2) minor negative to slightly positive $\mathrm{La}$ anomalies with $\mathrm{La} / \mathrm{La}^{*}$ from 0.82 to 1.37 ; (3) slightly negative to slightly positive $\mathrm{Ce}$ anomalies, with $\mathrm{Ce} / \mathrm{Ce}^{*}$ from 0.53 to 1.30 ; (4) markedly positive Eu anomalies with $\mathrm{Eu}^{*} / \mathrm{Eu}$ from 1.77 to 3.28; (5) positive $\mathrm{Gd}$ anomalies with $\mathrm{Gd} / \mathrm{Gd}^{*}$ from 1.39 to 2.08; and (6) minor LREE depletion to moderate LREE enrichment, with $(\mathrm{Nd} / \mathrm{Yb})_{N}$ from 0.55 to 2.09 and $(\mathrm{Pr} / \mathrm{Yb})_{N}$ from 0.41 to 1.85 .

Modern seawater composition is characterized by: (1) positive La anomaly; (2) negative Ce anomaly; (3) positive Gd anomaly; (4) supra-chondritic ratio (ppm) for Y/Ho (i.e. >40); and (5) LREE and MREE depletion, relative to $\operatorname{HREE}\left(\mathrm{La}_{N} / \mathrm{Yb}_{N}<1 ; \mathrm{Gd}_{N} / \mathrm{Yb}_{N}<1\right)$ [32]. The PAAS-normalized REE patterns for the carbonate samples are dramatically different from modern marine signatures as shown by the presence of little to no heavy REE enrichment $\left([\mathrm{Nd} / \mathrm{Yb}]_{N} 0.55-2.09\right.$, average 1.21), convex shape (middle REE enriched, BSI 1.50-2.16, average 1.76), the presence of slightly positive Eu anomalies, an average of 1.95 , and little to no negative $\mathrm{Ce}$ anomalies (Ce $\mathrm{e}^{*} \mathrm{Ce} 0.53-1.30$, average 0.95 ). The PAAS-normalized REE patterns of the dolostones share similarities with the ferruginous water in modern acidic ferruginous lakes [32]. 
Table 1. Compositions of trace element Th, Mn, and rare earth elements (REE) from the carbonate rocks of the Nantuo Formation.

\begin{tabular}{|c|c|c|c|c|c|c|c|c|c|c|c|c|c|c|c|c|c|c|}
\hline $\begin{array}{c}\text { Sample } \\
\text { No. }\end{array}$ & $\begin{array}{l}\text { Stratigraphic } \\
\text { Height (m) }\end{array}$ & Th & Mn & La & $\mathrm{Ce}$ & Pr & $\mathrm{Nd}$ & Sm & Eu & Gd & $\mathrm{Tb}$ & Dy & Ho & Er & $\mathrm{Tm}$ & $\mathrm{Yb}$ & Lu & TREE \\
\hline ZK201-1 & 0.07 & 0.389 & 2476 & 2.180 & 5.412 & 0.722 & 3.335 & 0.750 & 0.230 & 1.230 & 0.160 & 0.814 & 0.145 & 0.391 & 0.037 & 0.236 & 0.031 & 15.67 \\
\hline ZK201-2 & 0.14 & 0.531 & 3081 & 2.768 & 6.881 & 1.005 & 4.730 & 1.088 & 0.300 & 1.728 & 0.212 & 1.098 & 0.199 & 0.530 & 0.062 & 0.324 & 0.047 & 20.97 \\
\hline ZK201-3 & 0.22 & 0.130 & 3054 & 0.957 & 2.219 & 0.289 & 1.219 & 0.184 & 0.130 & 0.416 & 0.044 & 0.258 & 0.043 & 0.110 & 0.013 & 0.091 & 0.011 & 5.98 \\
\hline ZK201-4 & 0.37 & 0.357 & 4577 & 1.326 & 3.093 & 0.373 & 1.582 & 0.217 & 0.149 & 0.467 & 0.055 & 0.292 & 0.053 & 0.120 & 0.017 & 0.093 & 0.012 & 7.85 \\
\hline ZK201-5 & 0.47 & 0.795 & 6025 & 2.597 & 5.636 & 0.805 & 3.856 & 0.803 & 0.229 & 1.321 & 0.172 & 0.958 & 0.179 & 0.517 & 0.063 & 0.380 & 0.053 & 17.57 \\
\hline ZK201-6 & 0.52 & 0.170 & 1774 & 0.536 & 1.246 & 0.154 & 0.697 & 0.071 & 0.043 & 0.241 & 0.024 & 0.143 & 0.025 & 0.059 & 0.007 & 0.044 & 0.006 & 3.30 \\
\hline ZK201-7 & 0.55 & 0.485 & 7507 & 2.673 & 5.134 & 0.586 & 2.414 & 0.396 & 0.158 & 0.697 & 0.085 & 0.482 & 0.100 & 0.266 & 0.029 & 0.176 & 0.024 & 13.22 \\
\hline ZK201-8 & 0.59 & 0.364 & 7367 & 1.568 & 3.371 & 0.369 & 1.546 & 0.221 & 0.176 & 0.525 & 0.059 & 0.365 & 0.072 & 0.219 & 0.026 & 0.154 & 0.025 & 8.70 \\
\hline ZK201-9 & 0.63 & 0.576 & 10890 & 3.736 & 7.690 & 1.025 & 4.774 & 0.980 & 0.530 & 1.502 & 0.200 & 1.027 & 0.219 & 0.642 & 0.074 & 0.415 & 0.056 & 22.87 \\
\hline ZK201-10 & 0.72 & 0.236 & 2052 & 1.078 & 2.993 & 0.488 & 2.769 & 0.862 & 0.223 & 1.256 & 0.162 & 0.921 & 0.165 & 0.442 & 0.054 & 0.344 & 0.047 & 11.80 \\
\hline ZK201-11 & 0.80 & 2.032 & 1010 & 5.637 & 8.626 & 1.610 & 7.398 & 1.617 & 0.395 & 2.027 & 0.241 & 1.176 & 0.185 & 0.462 & 0.057 & 0.295 & 0.039 & 29.77 \\
\hline ZK201-12 & 0.87 & 1.167 & 906 & 5.029 & 5.017 & 1.200 & 5.216 & 0.905 & 0.271 & 1.292 & 0.144 & 0.770 & 0.121 & 0.319 & 0.039 & 0.208 & 0.028 & 20.56 \\
\hline ZK201-13 & 0.95 & 0.571 & 3146 & 4.914 & 6.988 & 1.135 & 5.027 & 0.862 & 0.186 & 1.033 & 0.123 & 0.649 & 0.123 & 0.307 & 0.031 & 0.200 & 0.028 & 21.60 \\
\hline ZK201-14 & 1.01 & 0.398 & 2548 & 1.795 & 2.962 & 0.439 & 2.061 & 0.378 & 0.155 & 0.768 & 0.088 & 0.432 & 0.079 & 0.215 & 0.027 & 0.182 & 0.023 & 9.60 \\
\hline ZK201-15 & 1.07 & 0.098 & 345 & 0.767 & 1.670 & 0.219 & 0.850 & 0.098 & 0.062 & 0.259 & 0.027 & 0.157 & 0.024 & 0.060 & 0.007 & 0.067 & 0.007 & 4.27 \\
\hline ZK201-16 & 1.16 & 0.201 & 482 & 1.688 & 3.631 & 0.517 & 2.181 & 0.332 & 0.158 & 0.640 & 0.071 & 0.394 & 0.061 & 0.141 & 0.019 & 0.104 & 0.013 & 9.95 \\
\hline ZK201-17 & 1.23 & 0.319 & 4421 & 1.700 & 4.488 & 0.514 & 2.646 & 0.709 & 0.291 & 1.279 & 0.157 & 0.976 & 0.179 & 0.502 & 0.067 & 0.402 & 0.054 & 13.97 \\
\hline ZK201-18 & 1.33 & 0.205 & 1116 & 0.705 & 1.646 & 0.215 & 1.005 & 0.181 & 0.096 & 0.357 & 0.049 & 0.291 & 0.054 & 0.181 & 0.021 & 0.139 & 0.018 & 4.96 \\
\hline
\end{tabular}


Table 2. Post-Archean Australian (PAAS)-normalized REE parameters calculated for the carbonates of the Nantuo Formation.

\begin{tabular}{ccccccccccc}
\hline Sample No. & $\mathbf{L a} / \mathbf{L a}^{*}$ & $\mathbf{C e} / \mathbf{C e}^{*}$ & $\mathbf{P r} / \mathbf{P r}{ }^{*}$ & $\mathbf{E u} / \mathbf{E u}$ & $\mathbf{B S I}$ & $\mathbf{( D y / S m})_{N}$ & $\mathbf{( N d / Y b})_{N}$ & $\mathbf{( P r} / \mathbf{Y b})_{N}$ & $\mathbf{( P r} / \mathbf{T b})_{N}$ & $\mathbf{( T b} / \mathbf{Y b})_{N}$ \\
\hline ZK201-1 & 1.01 & 1.00 & 0.98 & 1.37 & 2.06 & 1.29 & 1.18 & 0.98 & 0.39 & 2.48 \\
ZK201-2 & 0.96 & 0.93 & 1.01 & 1.27 & 2.05 & 1.20 & 1.21 & 0.99 & 0.41 & 2.39 \\
ZK201-3 & 0.93 & 0.94 & 1.02 & 3.02 & 1.81 & 1.66 & 1.11 & 1.01 & 0.57 & 1.78 \\
ZK201-4 & 1.01 & 1.02 & 0.99 & 2.89 & 1.66 & 1.60 & 1.41 & 1.28 & 0.59 & 2.16 \\
ZK201-5 & 1.16 & 0.97 & 0.99 & 1.27 & 1.72 & 1.42 & 0.84 & 0.68 & 0.41 & 1.65 \\
ZK201-6 & 1.13 & 1.07 & 0.96 & 2.31 & 1.75 & 2.39 & 1.32 & 1.12 & 0.56 & 1.99 \\
ZK201-7 & 1.22 & 1.04 & 0.98 & 1.77 & 1.48 & 1.44 & 1.14 & 1.06 & 0.60 & 1.76 \\
ZK201-8 & 1.17 & 1.11 & 0.95 & 3.28 & 1.43 & 1.96 & 0.84 & 0.77 & 0.55 & 1.40 \\
ZK201-9 & 1.24 & 1.01 & 0.98 & 2.44 & 1.60 & 1.24 & 0.96 & 0.79 & 0.45 & 1.77 \\
ZK201-10 & 1.11 & 1.01 & 0.93 & 1.20 & 2.16 & 1.27 & 0.67 & 0.45 & 0.26 & 1.73 \\
ZK201-11 & 1.16 & 0.71 & 1.12 & 1.22 & 2.04 & 0.86 & 2.08 & 1.74 & 0.58 & 2.99 \\
ZK201-12 & 1.24 & 0.53 & 1.25 & 1.47 & 1.72 & 1.01 & 2.09 & 1.85 & 0.73 & 2.53 \\
ZK201-13 & 1.33 & 0.79 & 1.09 & 1.10 & 1.54 & 0.89 & 2.09 & 1.81 & 0.81 & 2.25 \\
ZK201-14 & 1.41 & 0.91 & 1.02 & 1.77 & 1.80 & 1.35 & 0.94 & 0.77 & 0.44 & 1.77 \\
ZK201-15 & 0.82 & 0.85 & 1.08 & 2.59 & 1.63 & 1.89 & 1.05 & 1.04 & 0.71 & 1.48 \\
ZK201-16 & 0.91 & 0.86 & 1.06 & 2.10 & 1.87 & 1.41 & 1.75 & 1.59 & 0.63 & 2.52 \\
ZK201-17 & 1.37 & 1.30 & 0.87 & 1.80 & 1.87 & 1.63 & 0.55 & 0.41 & 0.28 & 1.43 \\
ZK201-18 & 1.13 & 1.04 & 0.97 & 2.16 & 1.50 & 1.91 & 0.60 & 0.49 & 0.38 & 1.30 \\
\hline
\end{tabular}

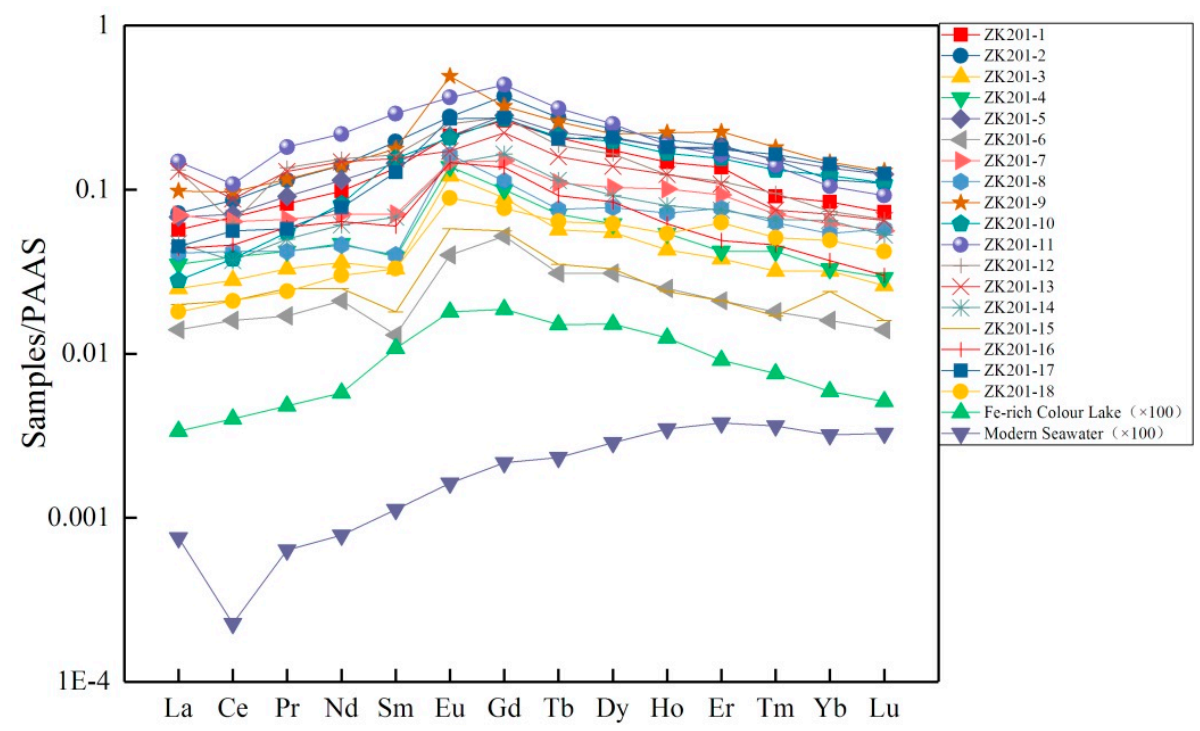

Figure 4. Comparisons of PAAS-normalized REE patterns among carbonate components from the Nantuo Formation Fe-rich Colour Lake [32], and modern oxic seawater [33].

\section{Discussion}

\subsection{Primary Deposit Evaluation}

It is essential to understand the origin of the studied carbonates in the Nantuo Formation. If the bedded dolostone was detrital in origin and derived from a pre-glacial dolostone through glacial erosion, the geochemical proxies of the carbonates would reflect the environment before the Marinoan glaciation. In the original Snowball Earth hypothesis, seawater would be undersaturated with carbonate minerals owing to the shutdown of alkalinity input from rivers, and dolomite could not be formed, given the very low $\mathrm{Mg} / \mathrm{Ca}$ ratio and temperature at the freezing point [1,34]. However, Gernon et al. argued that $\mathrm{Ca}^{2+}$ and $\mathrm{Mg}^{2+}$ supersaturation caused by widespread hyaloclastite alteration allowed the deposition of dolostone during and after the global glaciations [35]. In fact, in the Nanhua Basin, pre-glaciation successions were dominated by sub-greenschist facies metamorphic siliciclastic rocks, volcanic rocks and marine siliciclastic rocks [36]. The reported dolostone was the Sturtian cap carbonate in the Nanhua Basin [37], and no carbonate clasts were found in diamictites from the Nantuo Formation. Stable carbon isotopic compositions $\left(\delta^{13} \mathrm{C}_{\text {carb }}\right)$ of the Sturtian cap carbonate ranged from $-4.52 \%$ o to $+3.23 \%$, much higher than in analytical dolostone samples (average $\delta^{13} C_{\text {carb }}-7.1 \%$, data not shown 
in this article) in the Nantuo Formation. Accordingly, dolostone in the Nantuo Formation is unlikely to have been formed by re-deposition from pre-glacial dolostone. Instead, the bedded dolostone in the Nantuo Formation was deposited primarily during the Marinoan glaciation.

\subsection{Evaluation of Contamination by Terrestrial Matter}

Marine carbonates generally have low concentrations of REE, meaning that contamination by non-carbonates such as silicates and oxides can influence carbonate REE contents and patterns. To reduce contamination introduced by non-carbonates, analytical protocols called for the use of dilute acetic acid to dissolve the dolostone samples, according to reference [16]. Samples were then checked using geochemical contamination factors (high field strength elements (HFSE), e.g., Th) to detect silicate and oxide contamination $[15,16]$.

REEs and other HFSEs, such as thorium, have very low concentrations in modern river waters and seawaters [38-41]. As a result, carbonate REE concentrations and patterns can be modified by terrestrial particulate matters (i.e., shale). The most widely used method for evaluating the contamination of shale is to investigate the correlation between REE concentrations and immobile elements such as $\mathrm{Th}, \mathrm{Zr}$, and Sc, which are abundant in shale (11.8 ppm, $210 \mathrm{ppm}$, and 16 ppm, respectively, in PAAS) but appear in significantly lower concentrations in low-temperature waters [41]. In addition, Y/Ho ratios in Phanerozoic carbonates have also been used to inspect shale contamination because pure marine carbonates have higher $\mathrm{Y} / \mathrm{Ho}$ ratios than shale [16]. However, Wallace et al. argued that $\mathrm{Y} / \mathrm{Ho}$ values in Neoproterozoic carbonates are lower than in modern sea waters and could be controlled by redox processes rather than resulting from silicate contamination [22]. Because $\mathrm{Zr}$ is mainly hosted by zircon which cannot be attacked by acetic acid and considering that Sc can be hosted by sulphide minerals [16], we preferred to use Th to track shale contamination. Terrestrial particulate matter contamination would systematically increase REE concentrations with Th contents. Good correlations exist between REE concentrations and the Th contents of the carbonate samples (Figure 5), suggesting that the carbonates were affected by contamination with the shale. However, if the shale contamination dominated REE concentrations of the carbonate samples, PAAS-normalized REE patterns should be flat, shale-like patterns with no element anomalies. This indicates that the shale contamination in the dolostones is negligible. Accordingly, we proposed that the PAAS-normalized REE patterns reflected the marine environment in which carbonates were deposited. An alternative and reasonable explanation for positive correlation of concentrations of REE and Th in the dolostone samples is the incorporation of near-shore colloidal and nano-particles related to Fe oxyhydroxide anoxic dissolution and scavenging. This is supported by the observed lack of a negative Ce anomaly in most of the studied carbonates. REE studies for meltwater and glacially-fed waters provide an analogue of the Cryogenian environment. The suggestion has been made that modern glacial meltwater could deliver significant amounts of particulate iron into surrounding coastal oceans in which iron oxide nanoparticulates occur as coatings or at the edges of sheet aluminosilicate minerals [42,43]. Nanoparticles and colloids serve as significant parts of REE and HFSE in modern meltwater and glacially-fed waters [44]. Large percentages of iron and manganese oxide nanoparticles and colloids and associated REE are removed by scavenging during coastal zone mixing [45] and subsequently incorporated into carbonate minerals as a result of reductive dissolution of iron and manganese oxyhydroxides once they enter anoxic water columns, as discussed in the following. 


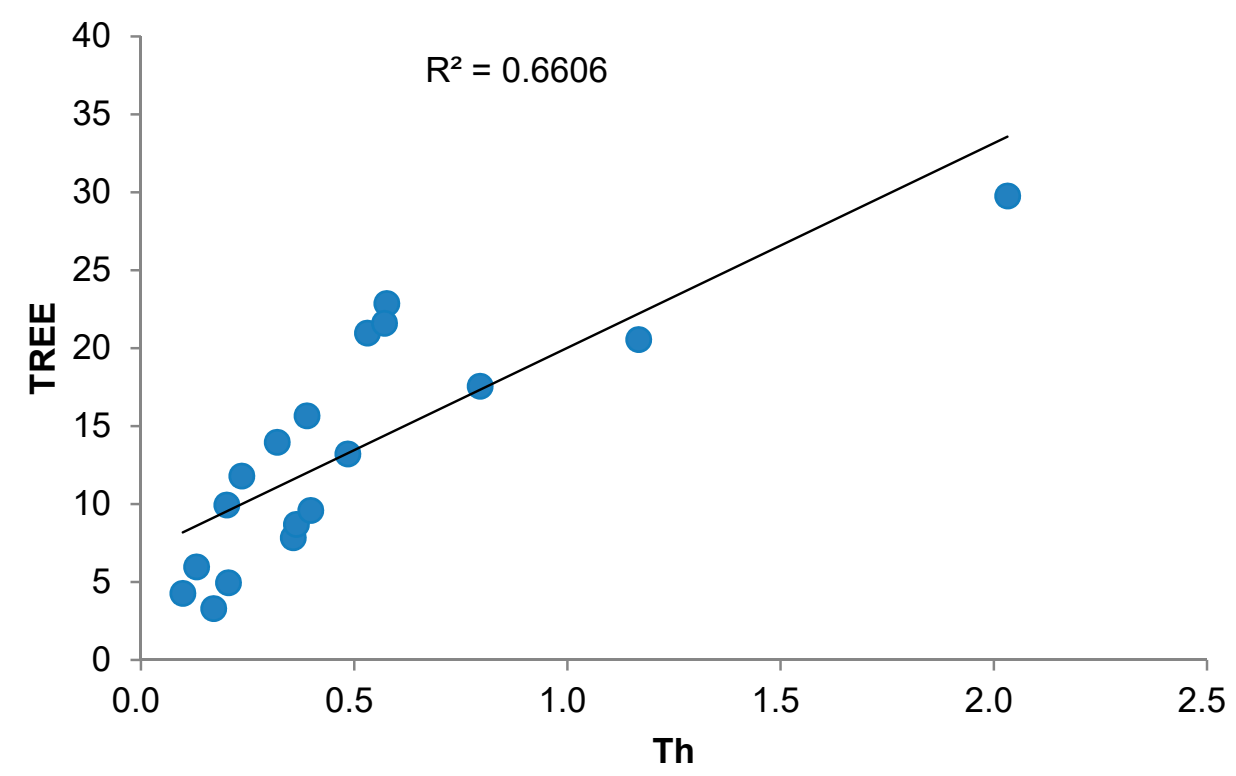

Figure 5. Positive correlation between the Th concentration and total REE concentration (TREE representing total REE concentration).

\subsection{The Influence of Diagenesis}

Owing to the large REE partition coefficients between the carbonate and seawater [46-49], early diagenetic models suggest that calcite REE patterns are less sensitive to post-deposition diagenetic alteration (including meteoric alteration and dolomitization) [38]. Well constrained variable diagenetic studies of REE distributions in ancient and modern limestones suggest that REE patterns, including Ce anomalies, are highly stable during meteoric processes, marine burial diagenesis, and dolomitization [47,50-53]. Taken together, carbonate REE patterns and Ce anomalies may record the seawater signatures of primary deposition.

\subsection{Marine Redox Conditions during Nantuo Glaciation}

The enrichment of MREE, the presence of weakly negative to slightly positive Ce anomalies, and the presence of pronounced positive Eu anomalies in the carbonates of the Nantuo Formation indicate an anoxic and iron-rich marine chemistry during the Nantuo glaciation. The reasons for the proposal are as follows: First, a lack of heavy REE enrichment is found in Precambrian anoxic marine basins to form iron formations [54]. Second, middle REE-enriched patterns are found in anoxic and/or ferruginous waters [32,55] and fossil biogenic apatite [56]. Because the analytical samples are carbonates, with no apatite observed under the microscope, middle REE enrichment patterns should be attributed to an anoxic and ferruginous environment, an interpretation supported by the elevated Mn concentrations in the samples (345-10,890 ppm), derived from anoxic dissolution of manganese oxides [55], a process likely to have occurred in oceans during the Marinoan glaciation. In modern anoxic waters with dissolved Mn and with no dissolved Fe present, PAAS-normalized REE showed linear patterns without MREE enrichment, whereas a distinctive MREE bulge-type pattern developed in anoxic waters with dissolved Mn and dissolved Fe [55].

Third, positive Eu anomalies in the REE patterns are interpreted as a suggestion of suboxic to anoxic ocean waters. A positive Eu anomaly is a typical feature of high-temperature hydrothermal alteration of ocean crust [57]. In contrast to the modern oxic marine environment, in which Ce negative anomalies are related to Ce (III) and oxidized and scavenged by Fe- and Mn-oxyhydroxide input from riverine or hydrothermal sources, the preservation of positive Eu anomaly signatures in shallow marine waters is compelling evidence for dominant marine anoxia in the Cryogenian oceans [58]. 
Fourth, negligible to positive Ce anomalies point to anoxic conditions, wherein the carbonates were deposited during the Marinoan glaciation. Ce is a redox sensitive element that is soluble in its trivalent form like other REEs, but less soluble in its tetravalent form. As a result, Ce is preferentially removed relative its neighboring $\mathrm{La}$ and $\mathrm{Pr}$ in modern oxic oceans causing a strong negative $\mathrm{Ce}$ anomaly to develop [19]. Under anoxic conditions, Ce anomaly is not well developed as a result of the reductive dissolution of $\mathrm{Fe}$ and $\mathrm{Mn}$ oxides [48]. Consequently, the Ce anomalies captured in ancient shallow-water carbonates could be a record of basin-scale redox conditions [22]. $\mathrm{Pr} / \mathrm{Pr}^{*}$ was used to distinguish real Ce anomalies from apparent ones, causing an overabundance of La relative to Ce [20]. If a sample has a $\operatorname{Pr} / \mathrm{Pr}^{*}$ value between 0.95 and 1.05, it is identified as a false Ce anomaly. Ce anomalies are much closer to unity, as indicated by samples ZK201-1-ZK201-10 and suggested shallow anoxic conditions (Figure 6.). Ce/Ce* values ranged from 0.53 to 0.87 (real Ce anomalies as identified by $\operatorname{Pr} / \operatorname{Pr} *$ ) in samples ZK201-11 to ZK201-16, indicating a transient oxygenation stage in shallow water. At the end of the carbonate deposition, the shallow water returned to anoxic conditions, as indicated by the slightly positive Ce anomaly seen in samples ZK201-17 and ZK201-18.

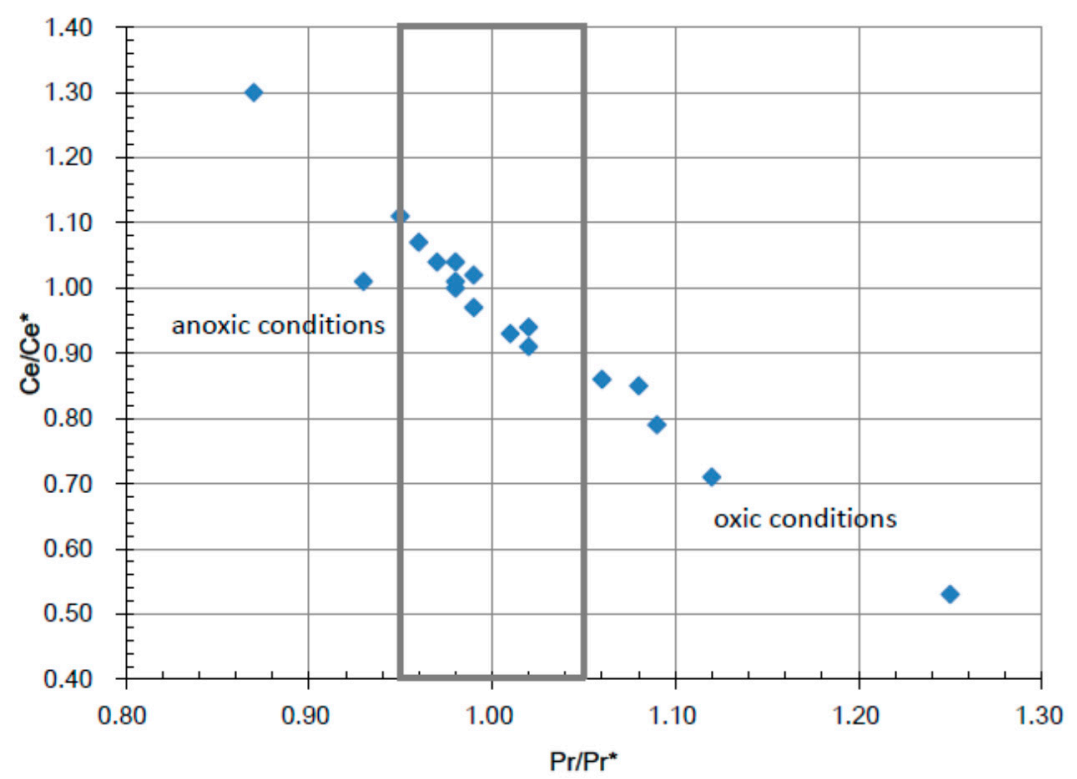

Figure 6. The cross-plot of $\mathrm{Ce} / \mathrm{Ce}{ }^{*}$ vs. $\mathrm{Pr} / \mathrm{Pr}^{*}$ for carbonates from the Nantuo Formation.

Taken together, all this suggests that an almost completely anoxic water column dominated, with transient oxic conditions, during the Marinoan glaciation in the Nanhua Basin. By combining our $\mathrm{Ce} / \mathrm{Ce}^{*}$ values in the Nantuo Formation with those in the Sturtian iron formation [59] and interglacial carbonates [60] between these two glaciations, we may construct a redox picture in the Cryogenian oceans. Globally developed iron formations within the Sturtian glacial successions show no negative Ce anomalies (Ce/Ce* average 1.05), pointing to anoxic and ferruginous conditions during the older and lengthy Neoproterozoic glaciation [59]. Near-shore carbonates in interglacial Cryogenian reef complexes in Australia have negligible to negative $\mathrm{Ce} / \mathrm{Ce}^{*}$ (average 0.92 ), revealing a very shallow chemocline (several metres) overlying the prevailing ferruginous water [60] - findings that have been corroborated by new REE data from central Australia [61]. The extreme ocean anoxic conditions during the Cryogenian Period were probably caused by the two Snowball Earth glaciations. In contrast, cap carbonates in the Doushantuo Formation of the Nanhua Basin had lower $\mathrm{Ce} / \mathrm{Ce}^{*}$ than in the Nantuo Formation [62], indicating an important oxygenation increase in the immediate aftermath of the Marinoan glaciation. However, a multi-proxy palaeoredox study of Ediacaran successions showed that Ediacaran oxygenation was transient [63]. We propose that prevailing anoxic oceans during the Cryogenian Period exerted a primary influence on subsequent ocean oxygenation and evolution of life after the Marinoan glaciation. 


\section{Conclusions}

Sedimentary carbonates from the lower units of the Nantuo Formation in eastern Guizhou Province correspond stratigraphically to the chemical sediments of the Marinoan ice age. These carbonates were geochemically analyzed for their REE and other trace elements to obtain a better understanding of the oceans at the time of the Marinoan glaciation. All the Nantuo Formation carbonates consistently showed similar REE patterns characterized by obvious MREE enrichment, slightly to no negative Ce anomalies, and positive Eu anomalies.

The combination of geochemical data and petrological evidence suggests that an anoxic and ferruginous water column dominated during the Marinoan glaciation with a thin oxic/suboxic layer restricted to coastal waters. Carbonates were precipitated from near shore environments that were affected by terrestrial particulate matters. Global Marinoan glaciation was probably the main cause of these anoxic and ferruginous conditions. Extreme ocean anoxia was dominant during the Cryogenian Period and constrained subsequent Ediacaran ocean oxygenation and the evolution of life.

Author Contributions: S.G. designed and supervised the project; Y.F. performed the experiments and analyzed the data; and J.L. performed the thin-section petrology of the samples. S.G. wrote this paper.

Funding: This research was funded by the National Natural Science Foundation of China (Nos. 41663005, 41762001).

Acknowledgments: We would like to thank the editors and anonymous reviewers for their helpful comments, which greatly improved the manuscript. Great thanks are also due to Yin Qin, Zhengze An, and Wenlang Qiao for their support of the field work and sample collection.

Conflicts of Interest: The authors declare no conflict of interest.

\section{References}

1. Hoffman, P.F.; Kaufman, A.J.; Halverson, G.P.; Schrag, D.P. A Neoproterozoic snowball earth. Science 1998, 281, 1342-1346. [CrossRef] [PubMed]

2. Xiao, S.; Knoll, A.H.; Yuan, X. Miaohe phyton, a possible brown alga from the terminal Proterozoic Doushantuo formation. China J. Paleontol. 1998, 72, 1072-1086. [CrossRef]

3. Narbonne, G.M. The Ediacara biota: Neoproterozoic origin of animals and their ecosystems. Annu. Rev. Earth Planet. Sci. 2005, 33, 421-442. [CrossRef]

4. Knoll, A.H.; Javaux, E.J.; Hewitt, D.; Cohen, P. Eukaryotic organisms in Proterozoic oceans. Philosz. Trans. R. Soc. B 2006, 361, 1023-1038. [CrossRef] [PubMed]

5. Och, L.M.; Shields-Zhou, G.A. The neoproterozoic oxygenation event: Environmental perturbations and biogeochemical cycling. Earth Sci. Rev. 2012, 110, 26-57. [CrossRef]

6. Johnson, B.W.; Poulton, S.W.; Goldblatt, C. Marine oxygen production and open water supported an active nitrogen cycle during the Marinoan Snowball Earth. Nat. Commun. 2017, 8, 1316. [CrossRef] [PubMed]

7. Corsetti, F.A.; Olcott, A.N.; Bakermans, C. The biotic response to Neoproterozoic Snowball Earth. Palaeogeogr. Palaeoclimatol. Palaeoecol. 2006, 232, 114-130. [CrossRef]

8. Parfrey, L.W.; Lahr, D.J.G.; Knoll, A.H.; Katz, L.A. Estimating the timing of early eukaryotic diversification with multigene molecular clocks. Proc. Natl. Acad. Sci. USA 2011, 108, 13624-13629. [CrossRef]

9. Ye, Q.; Tong, J.; Xiao, S.; Zhu, S.; An, Z.; Tian, L.; Hu, J. The survival of benthic macroscopic phototrophs on a Neoproterozoic snowball Earth. Geology 2015, 43, 507-510. [CrossRef]

10. Vincent, W.F.; Howard-Williams, C. Life on snowball Earth. Science 2000, 287, 2421. [CrossRef]

11. Vincent, W.F.; Gibson, J.A.E.; Pienitz, V.V.; Broady, P.A.; Hamilton, P.B.; Howard-Williams, C. Ice shelf microbial ecosystems in the high Arctic and implications for life on Snowball Earth. Naturwissenschaften 2000, 87, 137-141. [CrossRef] [PubMed]

12. Hoffman, P.F. Cryoconite pans on Snowball Earth: Supraglacial oases for Cryogenian eukaryotes? Geobiology 2016, 14, 531-542. [CrossRef] [PubMed]

13. Hawes, I.; Jungblut, A.D.; Matys, E.D.; Summons, R.E. The "Dirty Ice" of the McMurdo Ice Shelf: Analogues for biological oases during the Cryogenian. Geobiology 2018, 16, 369-377. [CrossRef] [PubMed] 
14. Pierrehumbert, R.T.; Abbot, D.S.; Voigt, A.; Koll, D. Climate of the Neoproterozoic. Annu. Rev. Earth Planet. Sci. 2011, 39, 417-460. [CrossRef]

15. Frimmel, H.E. Trace element distribution in Neoproterozoic carbonates as palaeoenvironmental indicator. Chem. Geol. 2009, 258, 338-353. [CrossRef]

16. Zhao, Y.Y.; Zheng, Y.F.; Chen, F.K. Trace element and strontium isotope constraints on sedimentary environment of Ediacaran carbonates in southern Anhui, South China. Chem. Geol. 2009, 265, 345-362. [CrossRef]

17. Nothdurft, L.D.; Webb, G.E.; Kamber, B.S. Rare earth element geochemistry of Late Devonian reefal carbonates, Canning Basin, Western Australia: Confirmation of seawater REE proxy in ancient limestones. Geochim. Cosmochim. Acta 2004, 68, 263-283. [CrossRef]

18. Shields, G.A.; Webb, G.E. Has the REE composition of seawater changed over geological time? Chem. Geol. 2004, 204, 103-107. [CrossRef]

19. De Baar, H.J.W.; Schjif, J.; Byrne, R.H. Solution chemistry of the rare earth elements in seawater. Eur. J. Solid State Inorg. Chem. 1991, 28, 357-373.

20. Bau, M.; Dulski, P. Comparing yttrium and rare earths in hydrothermal fluids from the Mid-Atlantic Ridge: Implications for $\mathrm{Y}$ and REE behaviour during near-vent mixing and for the $\mathrm{Y} / \mathrm{Ho}$ ratio of Proterozoic seawater. Chem. Geol. 1999, 155, 77-90. [CrossRef]

21. Kamber, B.S.; Webb, G.E. The geochemistry of late Archaean microbial carbonate: Implications for ocean chemistry and continental erosion history. Geochim. Cosmochim. Acta 2001, 65, 2509-2525. [CrossRef]

22. Wallace, M.W.; Hood, S.; Shuster, A.; Noah, A.G.; Planavsky, J.; Ree, C.P. Oxygenation history of the Neoproterozoic to early Phanerozoic and the rise of land plants. Earth Planet. Sci. Lett. 2017, 466, 12-19. [CrossRef]

23. Condon, D.; Zhu, M.; Bowring, S.A.; Wang, W.; Yang, A.; Jin, Y. U-Pb ages from the Neoproterozoic Doushantuo Formation, China. Science 2005, 308, 95-98. [CrossRef] [PubMed]

24. Zhang, S.; Jiang, G.; Han, Y. The age of the Nantuo Formation and Nantuo glaciation in South China. Terra Nova 2008, 20, 289-294. [CrossRef]

25. Zhang, Q.R.; Chu, X.L.; Feng, L.J. Neoproterozoic glacial records in the Yangtze region, China. In The Geological Record of Neoproterozoic Glaciations; Arnaud, E., Halverson, G.P., Shields-Zhou, G., Eds.; The Geological Society Publishing House: Bath, UK, 2011; pp. 357-366.

26. Jiang, G.; Shi, X.; Zhang, S.; Wang, Y.; Xiao, S. Stratigraphy and paleogeography of the Ediacaran Doushantuo Formation (ca. 635-551Ma) in South China. Gondwana Res. 2011, 19, 831-849. [CrossRef]

27. Lang, X.; Chen, J.; Cui, H.; Man, L.; Huang, K.J.; Fu, Y.; Zhou, C.; Shen, B. Cyclic cold climate during the Nantuo Glaciation: Evidence from the Cryogenian Nantuo Formation in the Yangtze Block, South China. Precambrian Res. 2018, 310, 243-255. [CrossRef]

28. McLennan, S.M. Rare earth elements in sedimentary rocks: Influence of provenance and sedimentary processes. In Reviews in Mineralogy; Lipin, B.R., McKay, G.A., Eds.; Mineralogical Society of America: Washington, DC, USA, 1989; pp. 170-200.

29. Lawrence, M.G.; Kamber, B.S. The behavior of the rare earth elements during estuarine mixing revisited. Mar. Chem. 2006, 100, 147-161. [CrossRef]

30. Tostevin, R.; Shields, G.A.; Tarbuck, G.M.; He, T.; Clarkson, M.O.; Wood, R.A. Effective use of cerium anomalies as a redox proxy in carbonate-dominated marine settings. Chem. Geol. 2016, 438, 146-162. [CrossRef]

31. Elderfield, H.; Upstillgoddard, R.; Sholkovitz, E.R. The rare-earth elements in rivers, estuaries, and coastal seas and their significance to the composition of ocean waters. Geochim. Cosmochim. Acta 1990, 54, 971-991. [CrossRef]

32. Johannesson, K.H.; Zhou, X. Origin of middle rare earth element enrichments in acid waters of a Canadian High Arctic lake. Geochim. Cosmochim. Acta 1999, 63, 153-165. [CrossRef]

33. Bolhar, R.; Kamber, B.S.; Moorbath, S.; Fedo, C.M.; Whitehouse, M.J. Characterisation of early Archaean chemical sediments by trace element signatures. Earth Planet. Sci. Lett. 2004, 222, 43-60. [CrossRef]

34. Jansen, M.F.; Nadeau, L.P. The effect of Southern Ocean surface buoyancy loss on the deep-ocean circulation and stratification. J. Phys. Oceanogr. 2016, 46, 3455-3470. [CrossRef]

35. Gernon, T.M.; Hincks, T.K.; Tyrrell, T.; Rohling, E.J.; Palmer, M.R. Snowball Earth ocean chemistry driven by extensive ridge volcanism during Rodinia breakup. Nat. Geosci. 2016, 9, 242-248. [CrossRef] 
36. Wang, J.; Li, Z. History of Neoproterozoic rift basins in South China: Implications for Rodinia break-up. Precambrian Res. 2003, 122, 141-158. [CrossRef]

37. Yu, W.; Algeo, T.J.; Du, Y.; Zhou, Q.; Wang, P.; Xu, Y.; Yuan, L.; Pan, W. Newly discovered Sturtian cap carbonate in the Nanhua Basin, South China. Precambrian Res. 2017, 293, 112-130. [CrossRef]

38. Goldstein, S.J.; Jacobsen, S.B. Rare-earth elements in river waters. Earth Planet. Sci. Lett. 1988, 89, $35-47$. [CrossRef]

39. Sholkovitz, E.R. The geochemistry of rare earth elements in the Amazon River estuary. Geochim. Cosmochim. Acta 1993, 57, 2181-2190. [CrossRef]

40. Sholkovitz, E.R. The aquatic chemistry of rare earth elements in rivers and estuaries. Aquat. Geochem. 1995, 1,1-34. [CrossRef]

41. Gaillardet, J.; Viers, J.; Dupré, B. Trace elements in river water. In Treatise on Geochemistry; Drever, J.I., Holland, H.D., Turekian, K.K., Eds.; Elsevier: Amsterdam, The Netherlands, 2003; Volume 5, pp. $225-272$.

42. Poulton, S.W.; Raiswell, R. Chemical and physical characteristics of iron oxides in riverine and glacial meltwater sediments. Chem. Geol. 2005, 218, 203-221. [CrossRef]

43. Bhatia, M.P.; Kujawinski, E.B.; Das, S.B.; Breier, C.F.; Henderson, P.B.; Charette, M.A. Greenland meltwater as a significant and potentially bioavailable source of iron to the ocean. Nat. Geosci. 2013, 6, 274-278. [CrossRef]

44. Tepe, N.; Bau, M. Importance of nanoparticles and colloids from volcanic ash for riverine transport of trace elements to the ocean: Evidence from glacial-fed rivers after the 2010 eruption of Eyjafjallajökull Volcano, Iceland. Sci. Total Environ. 2014, 488-489, 243-251. [CrossRef] [PubMed]

45. Tepe, N.; Bau, M. Distribution of rare earth elements and other high field strength elements in glacial meltwaters and sediments from the western Greenland Ice Sheet: Evidence for different sources of particles and nanoparticles. Chem. Geol. 2015, 412, 59-68. [CrossRef]

46. Zhong, S.; Mucci, A. Partitioning of rare earth elements (REEs) between calcite and seawater solutions at $25^{\circ} \mathrm{C}$ and $1 \mathrm{~atm}$, and high dissolved REE concentrations. Geochim. Cosmochim. Acta 1995, 59, 443-453. [CrossRef]

47. Webb, G.E.; Kamber, B.S. Rare earth elements in Holocene reefal microbialites: A new shallow seawater proxy. Geochim. Cosmochim. Acta 2000, 64, 1557-1565. [CrossRef]

48. Kamber, B.S.; Webb, G.E.; Gallagher, M. The rare earth element signal in Archaean microbial carbonate: Information on ocean redox and biogenicity. J. Geol. Soc. Lond. 2014, 171, 745-763. [CrossRef]

49. Zhao, M.Y.; Zheng, Y.F. Marine carbonate records of terrigenous input into Paleotethyan seawater: Geochemical constraints from Carboniferous limestones. Geochim. Cosmochim. Acta 2014, 141, 508-531. [CrossRef]

50. Della Porta, G.; Webb, G.E.; McDonald, I. REE patterns of microbial carbonate and cements from Sinemurian (Lower Jurassic) siliceous sponge mounds (Djebel Bou Dahar, High Atlas, Morocco). Chem. Geol. 2015, 400, 65-86. [CrossRef]

51. Banner, J.L.; Hanson, G.N. Calculation of simultaneous isotopic and trace element variations during water-rock interaction with applications to carbonate diagenesis. Geochim. Cosmochim. Acta 1990, 54, 3123-3137. [CrossRef]

52. Webb, G.E.; Nothdurft, L.D.; Kamber, B.S.; Kloprogge, J.T.; Zhao, J.X. Rare earth element geochemistry of scleractinian coral skeleton during meteoric diagenesis: A sequence through neomorphism of aragonite to calcite. Sedimentology 2009, 56, 1433-1463. [CrossRef]

53. Liu, X.M.; Hardisty, D.S.; Lyons, T.W.; Swart, P.K. Evaluating the fidelity of the cerium paleoredox tracer during variable carbonate diagenesis on the Great Bahamas Bank. Geochim. Cosmochim. Acta 2019, 248, $25-42$. [CrossRef]

54. Bau, M.; Möller, P. Rare earth element systematics of the chemically precipitated component in Early Precambrian iron formations and the evolution of the terrestrial atmosphere lithosphere system. Geochim. Cosmochim. Acta 1993, 57, 2239-2249. [CrossRef]

55. Haley, B.A.; Klinkhammer, G.P.; McManus, J. Rare earth elements in pore waters of marine sediments. Geochim. Cosmochim. Acta 2004, 68, 1265-1279. [CrossRef]

56. Auer, G.; Reuter, G.; Hauzenberger, C.A.; Piller, W.E. The impact of transport processes on rare earth element patterns in marine authigenic and biogenic phosphates. Geochim. Cosmochim. Acta 2017, 235, 140-156. [CrossRef] 
57. Bau, M. Rare-earth element mobility during hydrothermal and metamorphic fluid-rock interaction and the significance of the oxidation state of europium. Chem. Geol. 1991, 93, 219-230. [CrossRef]

58. Hood, A.V.S.; Wallace, M.W. Marine cements reveal the structure of an anoxic, ferruginous Neoproterozoic ocean. J. Geol. Soc. 2014, 171, 741-744. [CrossRef]

59. Lechte, M.; Wallace, M. Sub-ice shelf ironstone deposition during the Neoproterozoic Sturtian glaciation. Geology 2016, 44, 891-894. [CrossRef]

60. Hood, A.V.S.; Wallace, M.W. Extreme ocean anoxia during the Late Cryogenian recorded in reefal carbonates of Southern Australia. Precambrian Res. 2015, 261, 96-111. [CrossRef]

61. Verdel, C.; Phelps, B.; Welsh, K. Rare earth element and ${ }^{87} \mathrm{Sr} /{ }^{86} \mathrm{Sr}$ step-leaching geochemistry of central Australian Neoproterozoic carbonate. Precambrian Res. 2018, 310, 229-242. [CrossRef]

62. Hohl, S.V.; Becker, H.; Jiang, S.Y.; Ling, H.F.; Guo, Q.; Struck, U. Geochemistry of Ediacaran cap dolostones across the Yangtze Platform, South China: Implications for diagenetic modification and seawater chemistry in the aftermath of the Marinoan glaciation. J. Geol. Soc. 2017, 174, 893-912. [CrossRef]

63. Sahoo, S.K.; Planavsky, N.J.; Jiang, G.; Kendall, B.; Owens, J.D.; Wang, X.; Shi, X.; Anbar, A.D.; Lyons, T.W. Oceanic oxygenation events in the anoxic Ediacaran ocean. Geobiology 2016, 14, 457-468. [CrossRef]

(C) 2019 by the authors. Licensee MDPI, Basel, Switzerland. This article is an open access article distributed under the terms and conditions of the Creative Commons Attribution (CC BY) license (http://creativecommons.org/licenses/by/4.0/). 